\title{
落札企業の地域性に着目した被指名実績と 工事成績評定との関係に関する統計分析
}

\author{
徳島大学大学院 \\ ○森本恵美*1 \\ 徳島大学大学院 \\ 滑川 達*2 \\ 和 歌 山 県 \\ 岡本太地*3 \\ 徳島大学大学院 \\ 山中英生 $* 4$
}

By Emi MORIMOTO, Susumu NAMERIKAWA, Taichi OKAMOTO and Hideo YAMANAKA

わが国における公共工事の入札・契約制度は，1993 年度以降，これまで様々な改革が進められてき た.しかしそれらの改革は，官製談合事件を発端とする政治的・社会的圧力に押される形で進められ ており，十分な制度改革・改善のパフォーマンス評価に基づいたマネジメント・サイクルが整備され て来たとは言い難い，本研究においては，以上のような認識のもと，指名競争入札中心時期の国土交 通省四国地方整備局における工事案件データを取り上げ，それらの工事成績評定と，(1落札率，(2)価 格競争状態，(3)落札企業の過去の工事成績評定実績，(4)落札企業の過去の当該工事地域における被指 名実績との関係それぞれについて，各種の統計的分析をおこなった．その結果，(4)落札企業の発注同 事務所内における過去の被指名回数が，工事成績評定との関係において，上記(1)〜 (4)の指標の範疇に おいて最も論理的整合性が高く，地域性を背景とする総合的企業評価に関するベンチマーク指標とし て今後の検討に值する指標であると考察するに至った.

【キーワード】地域性, 制度パフォーマンス評価, 入札結果情報, 工事成績評定

\section{1. 序論}

\section{(1) 公共調達制度改革の経緯}

我が国の公共調達制度は，明治時代に制定された会 計法がほぼ原型のまま継続しており，特筆すべき変更 点としては，大正の時代において指名競争入札が但し 書きとして追加された程度である. そして，ここ 15 年程度前までは，この但し書きとしての指名競争入札 が運用上においては，メインシステムとして長期間安 定的に機能し，日本の高度経済成長を静かに支えてき た.

しかし 1993 年の金丸前自民党副総裁の逮捕以降，公 共事業を巡る大規模な贈収賄事件が次々と摘発され, 仙台市長, 茨城県知事, 宮城県知事等の首長や大手ゼ ネコンの最高幹部等が逮捕されるに至る「ゼネコン污
職事件」という国内事情 ${ }^{1)}$ と，新たな GATT 政府調達 協定 ${ }^{2)}$ に関する交渉の進展という，国際事情が相まっ て，既存の公共工事発注システムが，国民の信頼回復 と国際化への対応という課題に迫られ，1つの転換期 を迎えることになった。

このとき政府は, 1993 年 7 月, 中央建設業審議会に 「公共工事に関する特別委員会」を設置し，大きな改 革に着手, 同年 12 月には同特別委員会が報告書を作 成，これに基づき，同審議会は，「公共工事に関する 入札・契約制度の改革について」 ${ }^{3)}$ を建設大臣に対し 建議した.この建議においては, 改革の基本的な視点 として

(1) 不正の起こりにくいシステム構筑のため, 入札 契約手続きの透明性，客観性，競争性を高める

*1 徳島大学大学院工学研究科博士後期課程

088-656-7619

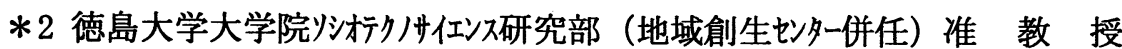

088-656-9877

$* 3$ 和歌山県 井都振興局 建設部

*4 徳島大学大学院汁行ク任ンス研究部（地域創生センター併任）教

授

088-656-7350 
こと

(2) 公共事業の質の低下及び工期の遅延等の防止

(3) 公共事業の円滑な執行 (入札・契約手続き及び 工事監督に要するコスト, 労力等の問題)

(4) 国際性を加味し, 外国企業の競争参加が容易に なるような条件の整備

の 4 項目をあげた上で，基本方針として次のような 提言を行った。

(1) 一定規模以上の大規模工事に限定した上で初め て一般競争方式の採用を積極的に提案した.

(2) 指名競争方式の改善として，指名基準及びその 運用基準の策定及び公表等従来対策の徹底に加 えて非指名理由等の説明, 第三者機関による苦 情処理等を提言するとともに, 建設業者の技術 力, 受注意欲を反映した指名競争方式として 「公募型」および「工事希望型」の指名競争方 式の導入を提案した.

(3) また, その他の入札・契約方式として技術提案 型総合評価方式の導入等にふれている.

この建議には, 概ね次のような基本思想が内在し ていると思われる.すなわち「一般競争入札の良い 点を限定的に導入しょう」「指名競争入札の良い点 を正当に評価した上で, 過度に硬直的となったルー ルを見直し，多様な方法をまずはやってみよう」 「その際には民間の技術力を大いに活用しよう」と いったものではないだろうか. 特に「多様な方法を まずはやってみよう」ということについては, 建議 の中で「実現可能なものから可及的速やかに実行に 移す」ことを求めていることからも明らかといえ, その奥には, その結果を様々な立場から検証し, 評 価しながら一般競争入札の大転換等については, 事 実関係に基づいてじっくり判断していくべきだとい う思想が伺われる。

その後, この建議内容を基本として, 1994 年 1 月 には「公共事業の入札・契約手続きの改善に関する 行動計画」 ${ }^{4)}$ が閣議了承されるとともに, 1998 年 2 月には, 中央建設業審議会が「建設市場の構造変化 に対応した今後の建設業の目指すべき方向」を建議 L, VE方式の導入, 有資格者の格付け公表, 予定 価格の事後公表等の改革 ${ }^{5)}$ も進んだ.

また, 2000 年 6 月には, 中尾栄一元建設大臣が, 大臣在任中に, 建設業者から受託収賄したとの容疑
で逮捕されるという事態の中で, 同年 10 月 「公共工 事の入札及び契約の適正化の促進に関する法律（以 後，「適正化法」）」が公布され，それに基づき 2001 年 3 月に「適正化指針」が閣議決定 ${ }^{6)}$ されてい るが，いずれも 1993 年建議の基本思想の枠をでるも のではない.

しかし，2005 年に発覚した国土交通省直轄の鋼橋 上部工事の発注に関する大規模な談合事件（橋梁談 合事件）が発端となり，国土交通省は，それまで堅 持してきた指名競争入札中心の入札方式から，一般 競争入札を原則とした入札方式に大転換を図り，一 般競争入札の拡大を柱とする, 入札談合再発防止対 策を打ち出した ${ }^{7)}$. また, 独占禁止法が改正され, 課徵金の引き上げ, 課徵金減免制度の導入等が行わ れた. すなわち 2005 年以降の改革は, システムの改 善ではなく, メインシステムの大転換といえる.

このメインシステムの大転換が, 1993 年建議が提 言したシステム改善努力の結果を十分に検証し, 評 価した上での決断であったかどうかという疑問は残 るが，世論がその余裕を与えなかったのも事実であ る.

いずれにせよ 2005 年度に施行された「公共工事の 品質確保の促進に関する法律 (以後, 「品確 法」）」 ${ }^{8)}$ も, 一般競争入札の拡大路線の文脈の中 に位置づけられるものであり, 指名競争入札にかわ る品質確保のための新たな仕組みづくりのスタート であるといえる.

\section{(2) 本研究の課題設定と本研究の目標}

2005 年度以降, 国土交通省は, 旧来の指名競争入 札から一般競争入札を原則とする入札方式へと大き く舵を切った.

しかし，これまで見てきたように，過去 15 年弱の 間, 公共工事の入札・契約制度改革の方向性につい ては, 様々な立場からの喧々諤々とした議論がなさ れてきた.マスコミ等は, これを「談合問題」や 「指名か一般か」といった形でシンプルに集約する が，それほど単純な議論ではなかったと言える.

これまでの議論の本質を, 完全に描くことは困難 であるが，概ね次の二つの思想のバランス，順序， スピードのあり方についてであると思われる. $1 つ$ は「建設産業の進歩のためには, 談合を阻止し, 競 争市場を実現することが久かせない，競争がなけれ 
ば価格は安くならないし, 品質も向上しない, 日本 の政府調達における最大の問題は, 競争が有効に機 能していないことである」という考え方であり， 1 つは「社会基盤のバージョンアップを担う, 公共事 業の品質をきちんと長期的に確保するためには, 信 頼のおける誠実な企業を絶え間なく育成し，その過 程の中で継続的・長期的な信頼関係の構築を重視す べきである.」という考え方であり，両者とも大切 にしなければならない思想といえる.

これら 2 つの思想は, 厳密には決して排他的では なく，相補的な関係とも言えなくはない。しかし， 典型的具体的手段となると，前者では「一般競争入 札の拡大」が効果的となり，後者では「指名競争入 札の改善」が効率的手段となり，この二元論となり 易い. また, 後者の継続的・長期的信頼関係の重視 は, 談合問題と紙一重の関係を有しており, 談合擁 護論と混同され易いため,世論的には一般競争入札 万能論に陥り易い性質を有している.さらに, 後者 の思想は, 地方部の自治体, 特にその対象となる行 政規模が小さくなるほど，地元建設業者の育成問題 とシンクロする部分が増してくるものとなる.すな わち, 昨今の, 国づくりの方向性の一つである, 地 方分権化や地方の自立といったキーワードに見られ る, 自律分散型システムという方向性においては, 信頼のおける誠実な企業の長期的育成と, 地元企業 の育成に重なりが生じるのも一定量必然と言える. しかし，これまでの日本の公共工事における，入 札・契約制度改革の発端が，すべて談合事件であっ たことや，これら事件に多くの地方自治体首長が関 係していたこともあり, 後者の思想に関しては, 公 に十分な議論が出来ない状況が続いてきたと言える.

すなわち, 我が国公共工事の入札・契約制度の中 に, 上述のような「地域性」という要素を, どのよ うに位置づけて行くべきか，ということについては， 今後多くの人々が真剣に議論・検討するに值する, 残された重要な課題の 1 つであると考える. 特に, 現状の国レベルの一般競争入札拡大を柱とする改革 が, 地方部の県レベル, 市町村レベルへ広がりを見 せはじめている昨今においては，なおさら重要であ る.

本研究においては，以上のような課題認識のもと， 今後の我が国における国レベル, 県レベルの主流と
なることが予想される「一般競争入札＋総合評価方 式」の枠組みの中で,「地域性」という要素をいか に位置づけるかと言うことについて，公共工事の結 果情報等の統計的分析を通して，その知見を得ると 共に，その知見をべースに，市町村レベルにおける 入札・契約制度改革の基本的方向性を探ることを最 終目標と設定している. そのため, 本研究において は, その第 1 ステップとして, 現状における結果情 報の入手可能性を鑑み, 指名競争入札をメインシス テムとしていた時代であるとともに，公共投資額の 急激な减少に伴う建設業界の過剩供給構造等により, 一部ではあるが受注を巡る価格競争性が高まった時 期である 2002 2005 年度の国土交通省四国地方整備 局における工事案件データを対象に，次のことを明 らかにするための統計的分析による実証研究を行っ た.

(1) 当該案件の工事成績評定と, 当該案件の落札率 及び価格競争状態といった価格指標とがどのよ うな関係にあるかを考察する。

(2) 当該案件の工事成績評定と, その落札企業の過 去の工事成績評定実績とがどのような関係にあ るか. 特に, 本研究が着目する地域性という観 点から, 四国地整全体及び当該案件の発注同事 務所内限定それぞれの工事成績評定実績と当該 案件の工事成績評定との関係を分析しその比較 的考察を試みる.

(3)「地域性（地域との関わりの深さ）」を総合的 に表す指標として, 落札企業の過去の当該工事 地域における被指名回数を採り上げ，これと工 事成績評定との関係性を分析・考察する.

\section{2. 分析データの概要}

\section{（1）分析データの背景}

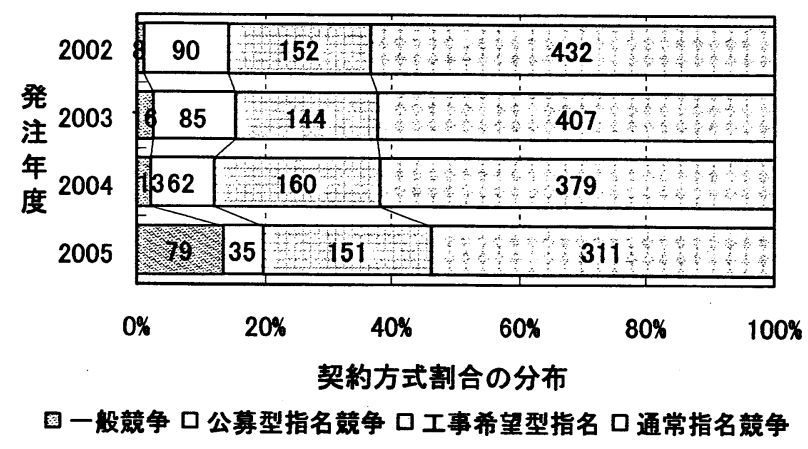

図-1 分析対象期間の四国地整工事入札契約方式 
本研究が分析対象とした 2002〜2005 年度は, 図-1 に示すように指名競争入札が大半を占めていた時期で ある. 一方で適正化法施行直後であり，インターネッ 卜等を通じ，入札参加者，応札金額，予定価格，落札 金額といった入札結果情報の公開義務付けが浸透し始 めた頃であった．また，公共投資の縮小と談合摘発強 化，建設市場の過剩供給が相まって，過当な価格競争 が危惧され始めた時期でもある.

国土交通省工事契約関係資料 ${ }^{9)}$ を元に，2002 年度 を 100 とした場合の 2005 年度の契約状況の割合を図2 に示す．有資格者数は，全地方整備局で 100 を超え ている. 比較して, 発注件数は 80-70, 工事の当初発 注金額の総額も 80-65 と，おおむね大幅な減少となっ ている.また，図-3 に示すように，2001～2005 年度 の全入札案件数にしめる低入札案件発生の割合は，各 地整で増加しており, 特に 2005 年度は, ほぼ倍増し ていることがわかる.

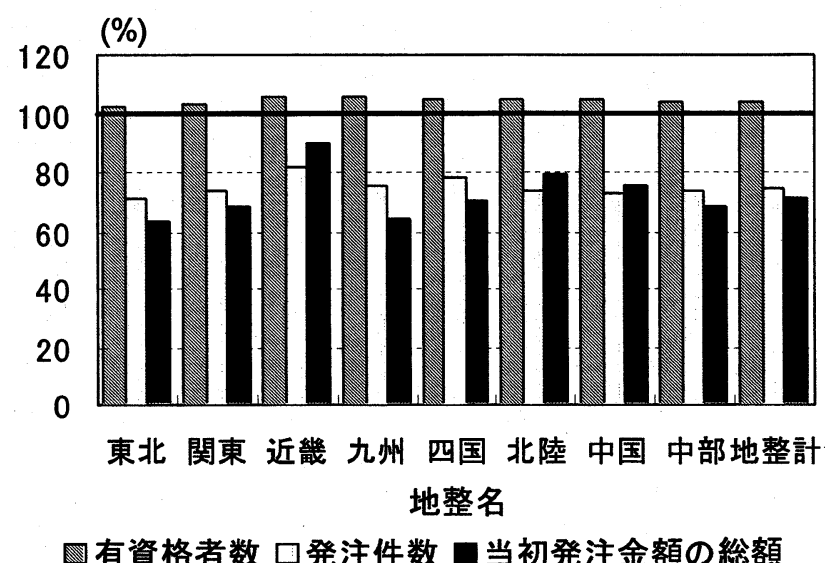

図-2 2002 年度の各值を 100 とした 2005 年度における有 資格者数・発注件数・工事の当初発注金額の総額の状況

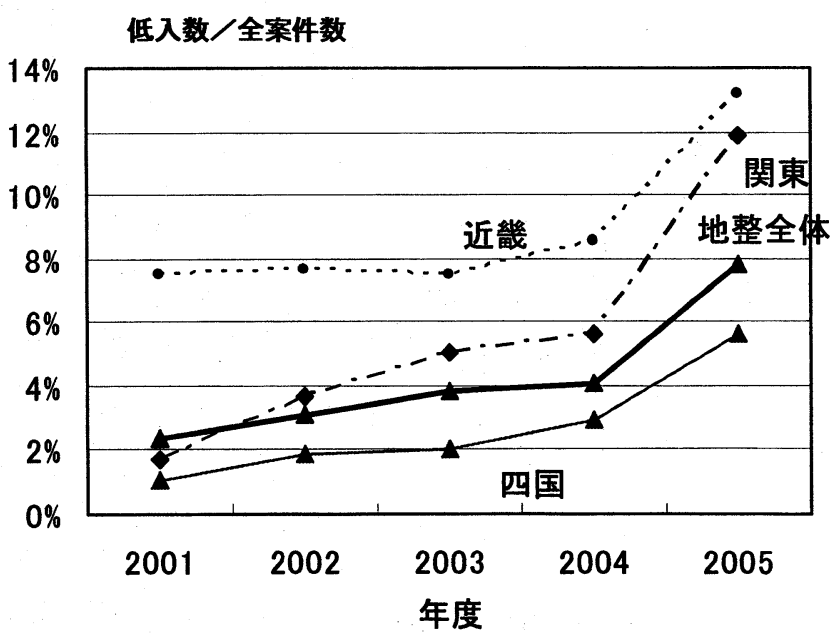

図-3 各地整における低入札案件発生の推移 ${ }^{9)}$

\section{（2）四国地方整備局工事結果データの概要}

\section{a) データの概要}

2002 2005 年度の 4 年間に四国地方整備局より発 注された工事データを用いる，本研究では，工事成績 評定と各種指標の関係性を対象とすることから，2007 年 8 月時点で, 工事成績評定の把握できた案件を分析 対象とした。 また，本研究において「案件」とは 1 工 事を示し，「入札数」とは入札参加企業による有効な 入札結果数のことである. 同様に「入札率」とは予定 価格に対する応札値のことであり，そのうち落札に至 った值を「落札率」と呼んでいる. 表-1 に分析に用 いたデータ概要及び平均值を示す.

\section{表-1 分析データの概要及び平均值}

\begin{tabular}{|c|r|r|r|r|}
\hline & \multicolumn{1}{c}{2002} & \multicolumn{1}{c}{2003} & \multicolumn{1}{c|}{2004} & \multicolumn{1}{c|}{2005} \\
\hline 案件数 & 670 & 637 & 584 & 368 \\
\hline 入札数 & 6650 & 6259 & 5607 & 3373 \\
\hline 平均落札率 & 0.951 & 0.954 & 0.957 & 0.942 \\
\hline 平均入札率 & 1.003 & 1.011 & 1.013 & 1.018 \\
\hline 平均成績評定 & 73.36 & 73.97 & 74.38 & 73.51 \\
\hline
\end{tabular}

\section{b) 落札率・ 入札率の年次推移}

2002 2005 年度の平均落札率，平均入札率の推移 を図 -4 に示す. 図 -4 の平均落札率は 2005 年度には最 も高い 2004 年度に対して 0.015 ポイント低下してい る. 2005 年度下半期より，一般競争入札の適用範囲 が拡大されたことも一因であると思われる。しかし， 平均入札率は，少しずつではあるが上昇傾向にある. 平均落札率が低下しているため，それらの差は 2002 年度には 0.05 ポイント程度であったが，2005 年度に は 0.076 ポイントに広がっている.

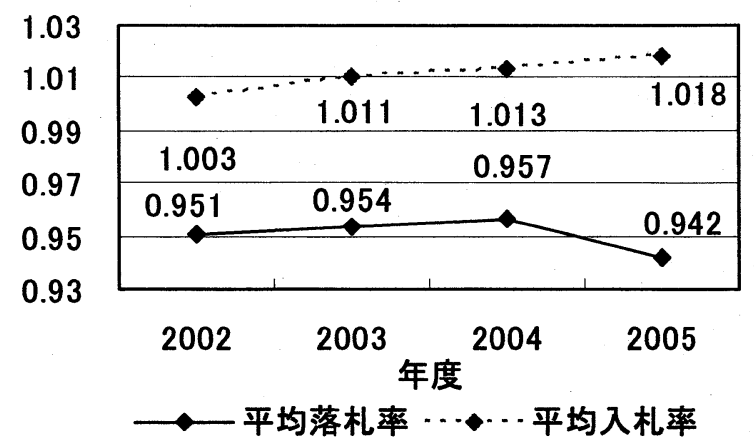

図-4 平均落札率と平均入札率の年次推移 


\section{c) 工事成績評定の年次推移}

図-5 に 2002〜2005 年度の工事成績評定年次推移を 示す. 4 年間の工事成績評定平均点は, 73.8 点である. 65 点未満の案件数は, 分析対象期間内にわたり低割 合存在するが，年度を追う毎に平均点である 73.8 点 以上の割合が増える傾向にあり，2005 年度全体では 4 年間の平均值である 73.8 点以上を 6 割以上が占める 結果となっているが， 80 点以上の非常に良い工事成 績評定は減少している．全体的な傾向としては，2002 〜2005 年度において，工事成績評定の大きな低下は みられない。

(年度)

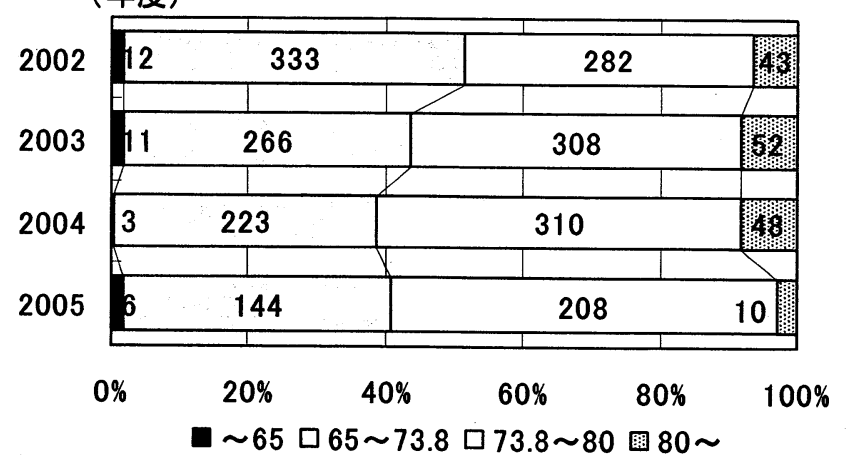

\section{図-5 工事成樍評定の年次推移}

\section{3. 四国地方整備局工事結果データの分析}

\section{(1) 工事成績評定}

ここでは，工事成績評定と各種指標の関係性を分 析する．まず表 -2 に示すように，工事成績評定は， 請負業者の適正な選定及び指導育成に資することを目 的として，原則的に 500 万円を超える案件に対し，発 注者が評価採点を行うものである. 65 土加減点（施 工体制, 状況, 出来ばえなど）に加え，高度技術，創 意工夫や社会性等を評価する ${ }^{10)}$.

2006 年 3 月に国土交通省全国工事監視官等会議で

\section{表-2 工事成績評定の評価項目}

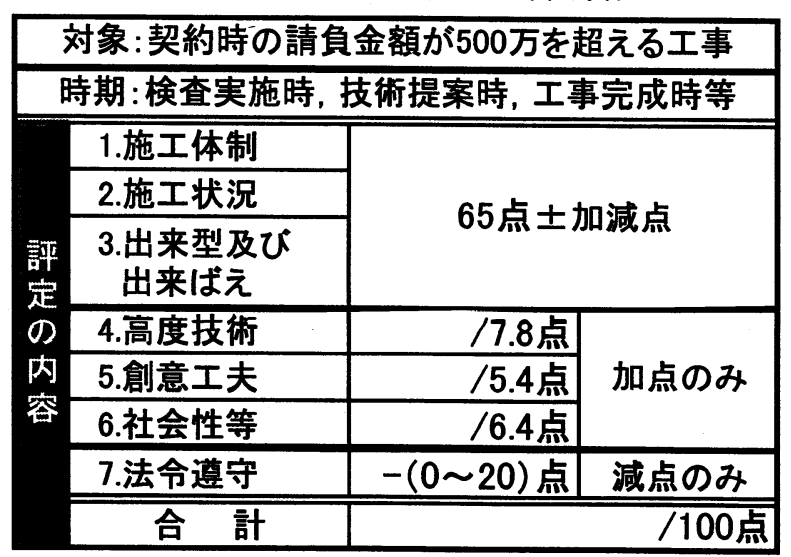

は, 詳細な統計分析を行った上で「落札率が低くなる ほど 65 点未満の点数を取る割合が増大すること, 品質, 安全対策, 工程管理など多くの項目で落札率が低くな るほど良い評価を得ることが難しくなる傾向がある」 と報告している ${ }^{11)}$.

しかし，工事成績評定については，評価方法に「施 工過程」のプロセス評価を含んでおり，必ずしも対象 構造物の完成後の品質だけを評価した值ではない，そ のため, 75 点より 69 点の工事の方が，品質が低いと いった相対的比較や傾向分析を工事成績評定を用いて 行っても, 必ずしも品質の高低のみが得られるもので はないとの疑問の声が上がるのも事実である.また， 品質を満たすことは，契約上当然のことであり，発注 者側がこれを検査した上で受け取った以上，品質に対 しては, 求められる一定レベルに達しているとの意見 もある.

例えば，1. 施工体制，2. 施工状況，3. 出来形およ び出来ばえ，の 3 項目の合計点は 65 点となるが， 3. 出来型及び出来ばえ, を除く 2 項目は, 施工プロセス の評価である.また，7. 法令遵守の減点は最大で 20 点と非常に厳しい評価が行われ, 構造物自体の品質が 高い場合でも工事成績評定は大きく減点されることに なる. 他方, 事故や施工体制の不良は, 結果として得 られる工事品質に影響することは当然として, 公共工 事として実施する事業を, 発注者がプロセス全体にわ たって評価することが妥当であるとも言える.

このように，工事成績評定は，品質を含む総合的 な評価指標といえる.

\section{(2) 分析の方法}

前述のように，工事成績評定を対象とした分析を行 う本研究では, 次のような 2 つの視点にたった分析・ 整理を試みる．まず，第一の視点としては，「工事成 績評定が施工プロセスを含む品質指標として一定の信 頼性・妥当性がある」ものと仮定した分析を試みる. 具体的には, 工事成績評定と (1)落札率, (2)価格競争状 態, (3)落札企業の過去の工事成績評定実績, (4)落札企 業の過去の当該工事地域における被指名実績, それぞ れとの関係を，分散分析及び相関・回帰分析を通して， 上記各指標の高低に対する工事成績評定の増減の傾向 分析を行う. 特に, 回帰分析においては, 上記各指標 (1)〜(4)それぞれを独立変数に有意水準 $5 \%$ による分析 を行い，各指標の高低に応じて工事成績評定が低下す 
る囘帰直線の傾きが誤差を見込んだ 95\%信頼区間にお いて有意かどうかを分析する．なお，この傾きの有意 性を分析する方法は，前述の国土交通省全国工事監視 官等会議による分析と同様の方法である.

続いて，第二の視点としては，前述の「検査後受け 取った以上，契約的には “求められる品質の担保”す るという義務を果たしている」という考え方に沿った 方法である．具体的には，基礎点である 65 点を下回 った工事案件のみに着目し，上記各指標(1)（4)それぞ れの高低の違いによる工事成績評定 65 点未満工事の 発生割合を整理・考察する. 加えて, 各指標(1)〜(4)そ れぞれについて工事成績評定 65 点未満の工事案件が 件数としてどのような区間に多く含まれているかを整 理することにより，工事成績評定 65 点未満工事の特 徽を考察する.

なお，以上のように $2 つ の$ 視点に大別される分析方 法には次のような問題を含んでいる．まず，第一の視 点に基づく分析では，仮定そのものの妥当性について 現状では十分な判断が困難であるため，その目的とし て分析手法の提示という意味合いが強くならざるを得 ない．また，第二の視点に基づく分析では，非常に少 数の工事案件サンプルにもとづく考察とならざれるを 得ず，考察結果の一般性が十分であるとはいえないこ とに留意する必要がある．しかし，以上のような問題 を含んでいるものの，これらの分析を複数・総合的に 実施した考察を通して今後への知見を蓄積していこう というのが，本研究における現状のスタンスである.

\section{(3) 工事成績評定と落札率との関係}

\section{a）分散分析結果}

落札率の各区間に含まれる案件群それぞれをグルー プとし, 工事成績評定を特性值とした分散分析の結果 を表-3 に示す．まず， $\mathrm{P}$ 值は極めて小さく統計的には 有意な結果を示した。 また，各グループの工事成績評 定の平均値は，落札率の低下とともに低下寸る傾向と なった.

表-3 落札率区分による工事成績評定の分散分析表

\begin{tabular}{|c|r|r|r|r|r|}
\hline \multicolumn{7}{|c|}{ 分 散 } & \multicolumn{1}{|c|}{ 分 析 } \\
\hline グループ & $60 \%$ 未満 & $60-70 \%$ & $70-80 \%$ & $80-90 \%$ & $90-100 \%$ \\
\hline 標本数 & 5 & 9 & 57 & 102 & 1609 \\
\hline 平均 & 69.00 & 64.56 & 71.33 & 72.21 & 74.35 \\
\hline 自由度 & \multicolumn{2}{|c|}{$(4,1777)$} \\
\hline P-值 & $1.676 \mathrm{E}-26 * *$ \\
\hline
\end{tabular}

b）相関，回帰分析結果

表-4 落札率・工事成績評定の回帰分析表

\begin{tabular}{|c|c|c|c|c|}
\hline 切片 & 傾き & 95\%下限の傾さ & 相関R & 観測数 \\
\hline 56.864 & 18.130 & 15.102 & 0.227 & 178 \\
\hline
\end{tabular}

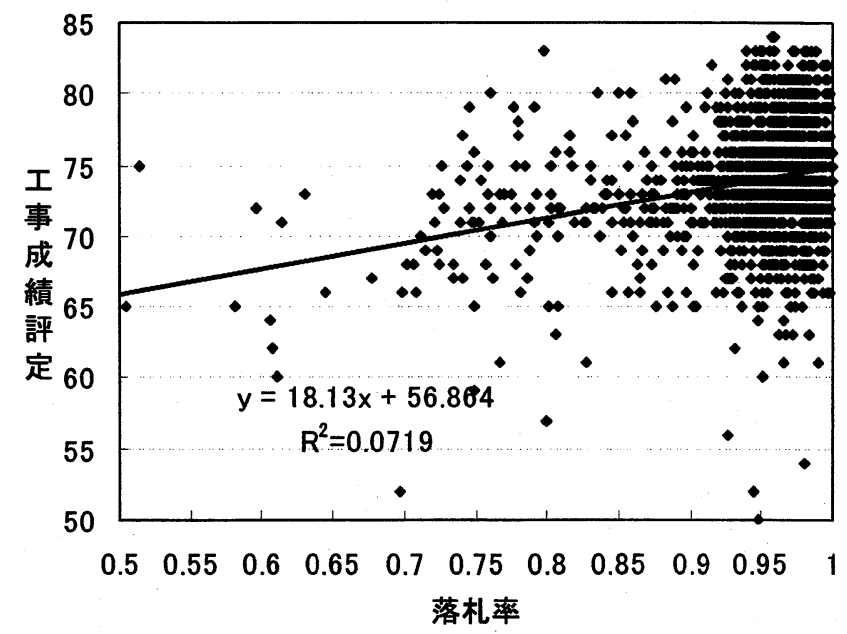

図-6＼cjkstart落札率・工事成績評定の散布図

工事成績評定を従属変数に, 落札率を独立変数に とった回帰分析の結果を，図-6 及び表-4 に示す．相 関係数は 0.227 , 決定係数は 0.072 と 1 対 1 の相関関 係は低い。一方，回帰直線の傾きの推定值は 18.13 となるが，誤差を見込んだ 95\%信頼区間内において， 傾きの下限值が 15.10 と解析された，従って，落札率 の増加に伴う工事成績評定の上昇度合い（傾き）は有 意に 0 とはならず，落札率が低くなるほど工事成績評 定が低くなる傾向が統計的には示される結果となった.

c）工事成績評定 65 点未満案件に着目した考察結果

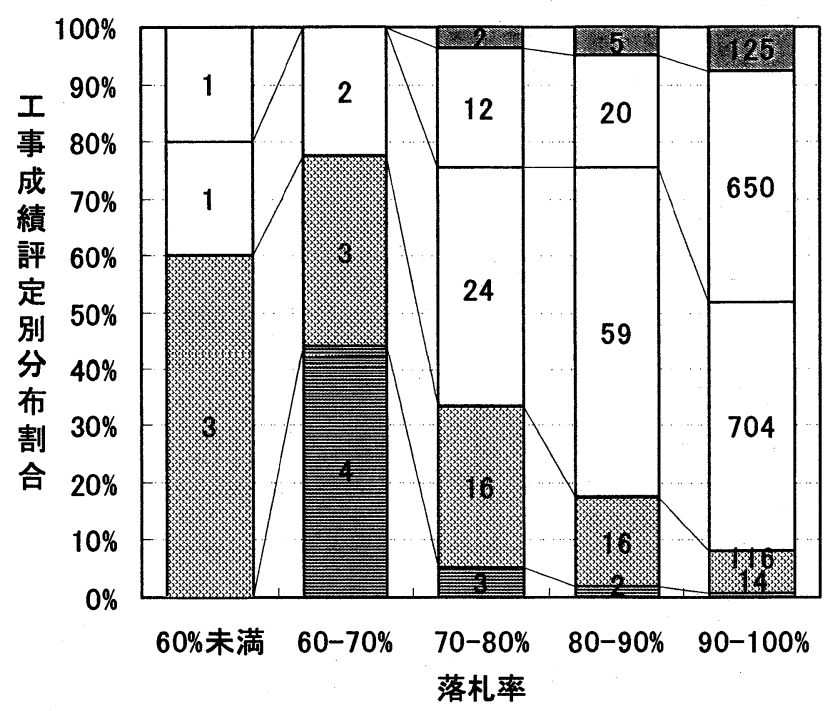

目65未満 图65-69 口70-74 口75-79 四80-84 図-7 落札率別・工事成績評定の件数割合 
落札率別・工事成績評定の件数割合の結果を図 -7 に, また工事成績評定 65 点未満の案件のみを対象と した落札率の件数割合を図-8 に示す. 図-7 の結果よ り, 落札率が低くなるほど 65 点未満の点数を取る割 合が増大する傾向が伺える．また，落札率が低くなる ほど 70 点以上の点数を取る割合が減少傾向となる結 果となった. しかし, 図-8 の結果からは, 工事成績 評定 65 点未満の案件の顕著な特徴が低落札率である とは必ずしも言えない結果を示している。

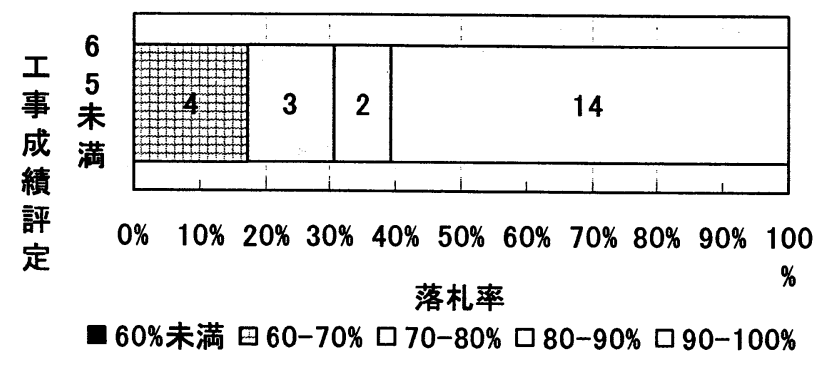

図-8 落札率分布状況から見た 65 点未満の工事案件

\section{（4）工事成績評定と価格競争状態との関係}

ここでは, 工事成績評定と入札值の分布形状とし て現れる価格競争状態の関係を分析する. なお，この 分析では, 企業の積算能力や態度により入札価格の精 度が異なることが, 結果としてばらつきの大きい入札 值の分布形状として現れるものと仮定した場合，その ことが工事成績評定にどのような影響を及ばすかとい うことを間接的ではあるが分析することも意味するも のと考えられる. 入札時の競争状態を判別する指標と して，式(1)のように定義される価格競争力 P の $75 \% \mathrm{Tile}$ (以下「 $\left.\mathrm{P}_{75}\right\rfloor$ ) を提案している.

$$
\begin{aligned}
& \mathrm{P}=\left(x_{i p}-x_{l p}\right) / x_{l p} \\
& x_{i p}=\text { 入札值 } \quad x_{l p}=\text { 落札值 }
\end{aligned}
$$

P は, 落札した企業が 0 をとり, 落札価格から離れ るほどその值は大きくなる， $\mathrm{P}_{75}$ とは，1案件の入札 值をすべて $\mathrm{P}$ に変換し, それらの第 3 四分位数を算出 したものである. 従って $\mathrm{P}_{75}$ が大きいほど入札值は広 く分布し（分散型競争）, 小さいほど狭い範囲に分布 （拮抗型競争）していると考えられる. 算出した $\mathrm{P}_{75}$ は, 入札值分布の形状を表す, 案件が個々に持つ值で ある. $\mathrm{P}_{75}$ による入札值の分布状態を全案件について 調べ, 入札値分布の特徵毎にその区分を試行錯誤的で はあるが設定した. 図-9 に, $\mathrm{P}_{75}$ の各区間による入札 参加企業の分布形状の概念図を示す. 全案件の目視確 認の結果, $\mathrm{P}_{75}$ が 0.12 を下回ると概ね拮抗型の競争状

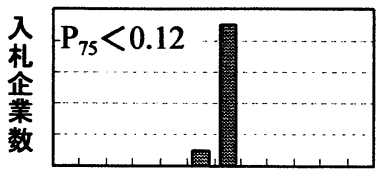

入 札事

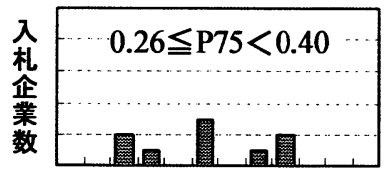

入札本

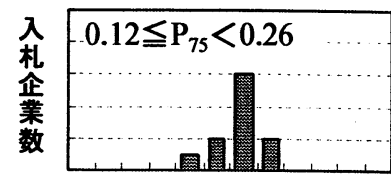

入札車

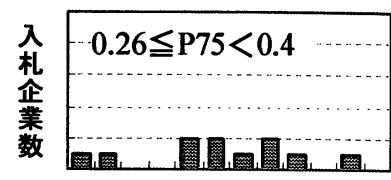

入札率
図-9 $P_{75}$ 各区間の入札参加企業分布形状概念図

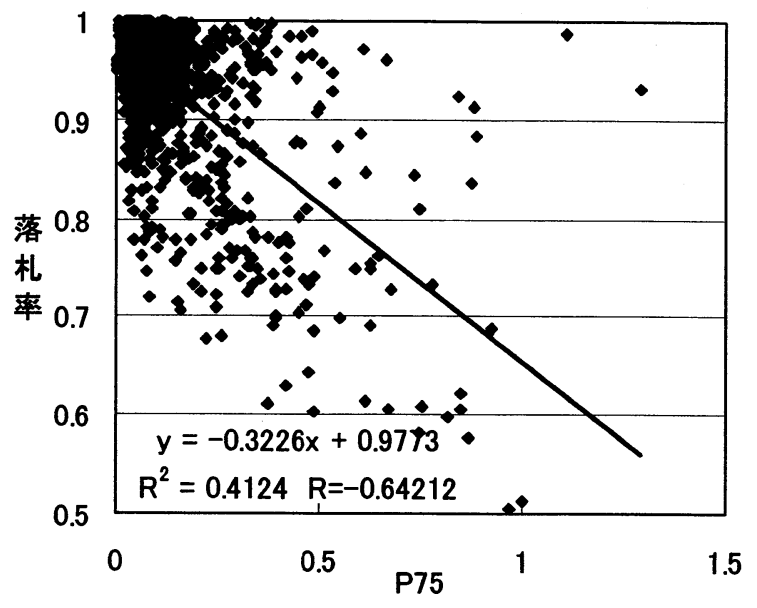

図-10 $\quad P_{75}$ 落札率の散布図

態を表し， 0.26 を上回ると概ね分散型の競争状態を 表すことが判っている. ここで， $\mathrm{P}_{75}$ と前述の落札率 との関係を図-10 に示す.この $\mathrm{P}_{75}$ は原理的には入札 值分布の形状のみを表現するものであり，価格帯のポ ジションは表現しないものであるが，図-10 をみても わかるように多くの案件が, 予定価格付近の拮抗型競 争状態となっており, 入札值形状が分散型，すなわち $\mathrm{P}_{75}$ が大きくなるほど落札率は低下傾向となる.なお, $\mathrm{P}_{75}$ と落札率の相関係数は 0.642 であった. しかし， 拮抗型であっても落札率の低い案件, 分散型であって も落札率の高い案件も少なからず存在している.

\section{a) 分散分析結果}

価格競争状態指標 $\mathrm{P}_{75}$ の各区間に含まれる案件群を グループとし，工事成績評定を特性値とした分散分析 の結果を表-5に示す．まず，P 值は極めて小さく統計 的には有意な結果を示した. また, 各グループの工事

\begin{tabular}{|c|c|c|c|c|}
\hline \multicolumn{5}{|c|}{$\begin{array}{lll}\text { 分 } & \text { 散 } & \text { 分 } \\
\end{array}$} \\
\hline グループ & $P_{75}<0.12$ & $0.12<P_{75} \leqq 0.26$ & $0.26 \leqq P_{75}<0.40$ & $0.40 \leqq P_{75}$ \\
\hline 標本数 & 1475 & 183 & 75 & 49 \\
\hline 平均 & 74.48 & 72.58 & 71.79 & 70.53 \\
\hline & & 1778) $P-1$ & $1.632 \mathrm{E}^{-2}$ & \\
\hline
\end{tabular}

表-5 P 75 区分による工事成績評定の分散分析表 
成績評定の平均值は， $\mathrm{P}_{75}$ の増大とともに低下する傾 向となった.

\section{b) 相関，回帰分析結果}

工事成績評定を従属変数に, 価格競争状態指標 $\mathrm{P}_{75}$ を独立変数にとった回帰分析の結果を, 図-11 及び 表-6 に示す. 相関係数は 0.246 , 決定係数は 0.061 と 1 対 1 の相関関係は低い。一方, 回帰直線の傾きの推 定值は-8.132 となるが，誤差を見込んだ 95\%信頼区間 内において，傾きの上限值が-6.645 と解析された. 従って, $\mathrm{P}_{75}$ の増加に伴う工事成績評定の下降度合い

（傾き）は有意に 0 とはならず， $\mathrm{P}_{75}$ が高く入札值の 分布が分散型になるほど工事成績評定が低くなる傾向 が統計的には示される結果となった。

表-6 $P_{75} \cdot$ 工事成績評定の回帰分析表

\begin{tabular}{|c|c|c|c|c|}
\hline \multicolumn{5}{|c|}{ 回 帰 分 } \\
\hline 切片 & 傾き & $95 \%$ 上限の傾き & 相関R & 観測数 \\
\hline 74.817 & -8.132 & -6.645 & 0.246 & 1782 \\
\hline
\end{tabular}

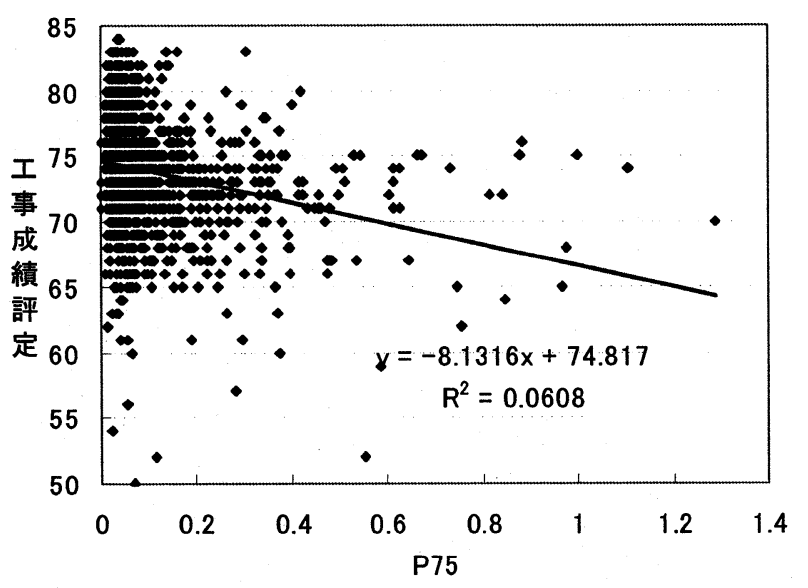

図-11 $\quad P_{75} \cdot$ 工事成績評定の散布図

\section{c）工事成績評定 65 点未満案件に着目した考察結果}

価格競争状態指標 $\mathrm{P}_{75}$ 別・工事成績評定の件数割合 の結果を図-12に，また工事成績評定 65 点未満の案 件のみを対象とした $\mathrm{P}_{75}$ の件数割合を図-13 に示す. 図-12 の結果より， $\mathrm{P}_{75}$ が高くなるほど 65 点未満の点 数を取る割合が増大する傾向が同える.また， $\mathrm{P}_{75}$ が 高くなるほど 70 点以上の点数を取る割合が減少傾向 となる結果となった。しかし，図-13 の結果からは， 工事成績評定 65 点未満の案件の顕著な特徽が分散型 の価格競争状態であるとは必ずしもいえない結果を示 している.

（5）工事成績評定と落札企業の前年度の四国地方整備 局全体における工事成績評定実績平均値との関係

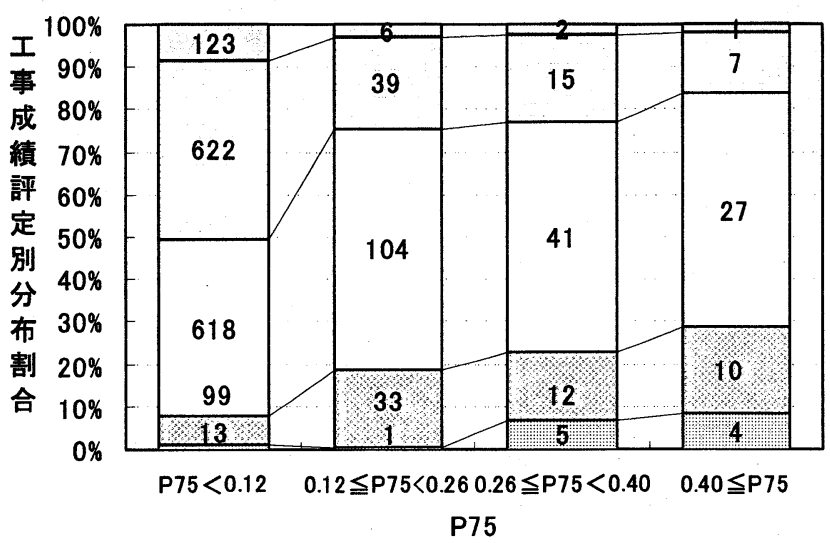

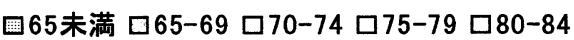
図-12 落札率別・工事成績評定の件数割合

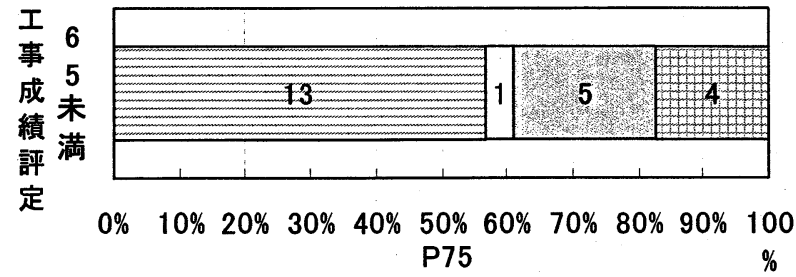

$\square P 75<0.12 \quad \square 0.12 \leqq P 75<0.26$ $\square 0.26 \leqq P 75<0.40 \boxminus 0.40 \leqq P 75$

図-13 $P_{75}$ 分布状況から見た 65 点未満の工事案件 以上では，工事成績評定と落札率や価格競争状態と いった「価格」に係わる指標との関係を分析したが， ここでは当該案件の工事成績評定と, その案件を落札 した企業の過去の四国地方整備局内における工事の仕 事ぶりや施工能力，具体的には落札企業の四国地方整 備局全体における前年度の工事成績評定実績平均值

（以下「落札企業の前年度工事成績評定平均（地整 全）」）上の関係を分析する。なお，前年度，四国地 方整備局内において, 契約実績がない, 及び随意契約 等本分析対象データに含まれない契約方式の実績, 当 初契約金額が 500 万以下の工事成績評定評価外の契約 実績はすべて「評点なし」とした．また，b)相関，回 帰分析からは除いた。

\section{a) 分散分析結果}

落札企業の前年度工事成績評定平均（地整全）の各 区間に含まれる案件群及び「評点なし（前年度，四国 地方整備局内において，契約実績がない，及び随意契 約等本分析対象データに含まれない契約方式の実績, 当初契約金額が 500 万以下の工事成績評定評価外の契 約実績）」案件群それぞれをグループとし，工事成績 評定を特性値とした分散分析の結果を表-7 に示す. まず，P 值は極めて小さく統計的には有意な結果を示 した。 また, 各グループの工事成績評定の平均值は, 
表-7 落札企業の前年度工事成績評定平均（地整全）

による工事成績評定の分散分析表

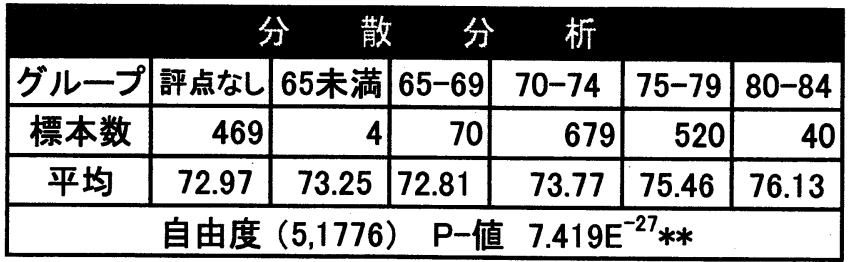

*「評点なし」とは前年度, 四国地方整備局内において，契約実績がな い，及ひ随意契約等本分析対象データに含まれない契約方式の実績， 当初契約金額が500万以下の工事成績評定評価外の契約実績

前年度工事成績評定平均（地整全）の低下と共に低下 する傾向となった.

b）相関，回帰分析結果

工事成績評定を従属変数に，落札企業の前年度工事 成績評定平均（地整全）を独立変数にとった回帰分析 の結果を，図-14 及び表-8に示す．また，この分析で は,「評点なし」企業群は除外した。相関係数は 0.268 , 決定係数は 0.072 と 1 対 1 の相関関係は低い. 一方, 回帰直線の傾きの推定值は 0.326 となるが, 誤差を見込んだ 95\%信頼区間内において，傾きの下限 值が 0.263 と解析された. 従って, 前年度工事成績 評定平均（地整全）の増加に伴う工事成績評定の上昇 度合い（傾き）は有意に 0 とはならず，落札企業の 前年度工事成績評定平均（地整全）が低くなるほど当 該案件の工事成績評定が低くなる傾向が統計的には示 される結果となった.

\section{c）工事成績評定 65 点未満案件に着目した考察結果}

表-8 落札企業の前年度工事成績評定平均

（地整全）・工事成績評定の回帰分析表

\begin{tabular}{|c|c|c|c|c|}
\hline \multicolumn{5}{|c|}{ 回 帰 分 } \\
\hline 切片 & 傾き & $95 \%$ 下限の傾き & 相関R & 観測数 \\
\hline 50.281 & 0.326 & 0.263 & 0.268 & 1313 \\
\hline
\end{tabular}

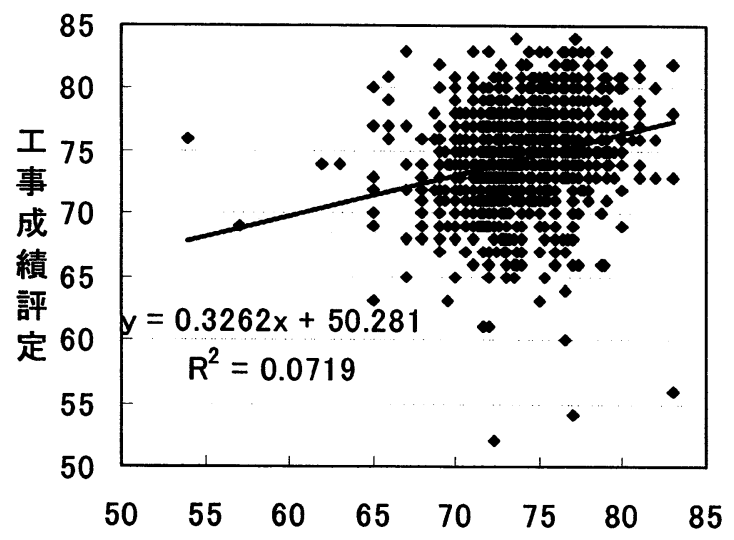

落札企業の前年度工事成績評定平均 (地整全)

図-14 落札企業の前年度工事成績評定平均

（地整全）・工事成績評定の散布図
落札企業の前年度工事成績評定平均（地整全） 別・工事成績評定の件数割合の結果を図-15 に，また 工事成績評定 65 点未満の案件のみを対象とした落札 企業の前年度工事成績評定平均（地整全）の件数割合 を図-16 に示す．図-15 の結果より，落札企業の前年 度工事成績評定平均（地整全）が低くなるほど 65 点 未満の点数を取る割合が増大する傾向はみえない。し かし，前年度の工事成績評定平均值が低くなるほど 70 点以上の点数を取る割合の減少傾向が，「評点な し」案件群を除き伺える結果となった。一方，図-16 の結果からは, 工事成績評定 65 点未満の案件の約 5.5 割が「評点なし」企業群による工事であるという 結果となった。

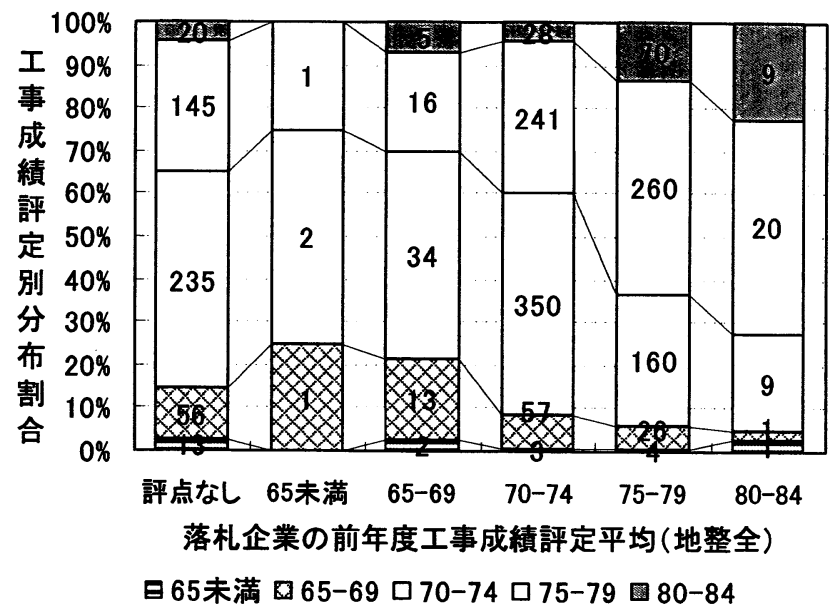

*「評点なし」とは前年度, 四国地方整備局内において契約実績がな い, 随意契約等本分析対象テータに含まれない契約方式の実績, 当初 契約金額が 500 万以下の工事成樍評定評価外の契約実績を示す.

図-15 落札企業の前年度工事成績評定平均

（地整全）別・工事成績評定の件数割合

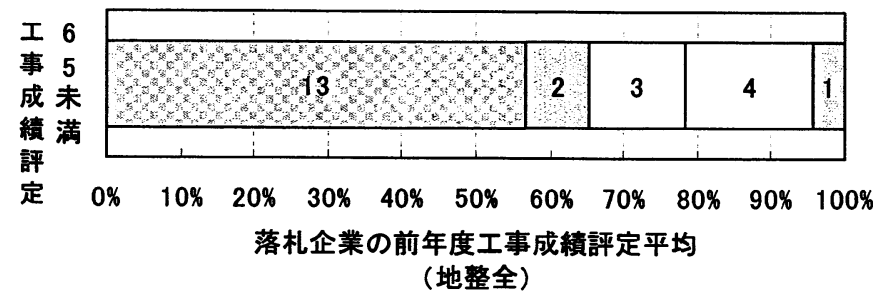

ロ評点なし ロ65未満 ロ65-69 ロ70-74 ロ75-79 ロ 80-84 *「評点なし」とは前年度, 四国地方整備局内において契約実績がな い, 随意契約等本分析対象テータに含まれない契約方式の実績, 当 初契約金額が 500 万以下の工事成樍評定評価外の契約実績を示す.

図-16 落札企業の前年度工事成績評定平均

（地整全）分布状況から見た 65 点未満の工事案件

（6）工事成績評定と落札企業の当該案件発注同事務所 内における工事成績評定実積との関係

前述（5）では，工事成績評定と落札企業の前年度 工事成績評定平均（地整全）との関係を分析した。さ 
らにここでは，より地域性を背景とした落札企業の過 去の仕事ぶりや施工能力，すなわち工事位置が特定さ れた個々の工事に対する施工能力をより表す指標とし て, 落札企業の当該案件発注同事務所内における前年 度の工事成績評定平均值（以下「落札企業の前年度工 事成績評定平均（発注同事務所）」）を採り上げ，当 該案件の工事成績評定との関係を分析する．なお，分 析対象工事発注事務所において, 前年度契約実績が無 い，随意契約等本分析対象データに含まれない契約方 式の実績，当初契約金額が 500 万以下の工事成績評定 評価外の契約実績はすべて「評点なし」とした。また， b)相関，回帰分析からは除いた.

\section{a) 分散分析結果}

落札企業の前年度工事成績評定平均（発注同事務 所）の各区間に含まれる案件群及び「評点なし（分析 対象工事発注事務所において，前年度，契約実績が無 い，随意契約等本分析対象データに含まれない契約方 式の実績，当初契約金額が 500 万以下の工事成績評定 評価外の契約実績）」案件群それぞれをグループとし， 工事成績評定を特性值とした分散分析の結果を表-9 に示す．まず，P 值は極めて小さく統計的には有意な 結果を示した. また，各グループの工事成績評定の平 均值は, 前年度の工事成績評定平均值の低下とともに 低下する傾向となった。

\section{表-9＼cjkstart落札企業の前年度工事成績評定平均（発注同事}

務所内）による工事成績評定の分散分析表

\begin{tabular}{|c|c|c|c|c|c|c|}
\hline & & 分 & 散 & 析 & & \\
\hline グループ & 評点なし & 65未満 & $65-69$ & $70-74$ & $75-79$ & $80-84$ \\
\hline 標本数 & 836 & 7 & 56 & 445 & 393 & 45 \\
\hline 平均 & 73.32 & 74.14 & 72.48 & 73.96 & 75.69 & 76.69 \\
\hline \multicolumn{7}{|c|}{ 自由度 $(5,1776) \quad \mathrm{P}$-值 } \\
\hline
\end{tabular}

*「評点なし」とは分析対象工事発注事務所において，前年度契約実績がない, 及ひ随意契約等本分析対象デー夕に含まれない契約方式の実績，当初契約 金額が500万以下の工事成績評定評価外の契約実績を示す。

\section{b）相関，回帰分析結果}

工事成績評定を従属変数に, 落札企業の前年度工事 成績評定平均（発注同事務所）を独立変数にとった回 帰分析の結果を, 図-17 及び表-10 に示す. なお, こ こでの回帰分析には，「評点なし」企業群を除外した サンプルを用いている. 相関係数は 0.292 , 決定係数 は 0.085 と 1 対 1 の相関関係は低いが，前述の落札企 業の前年度工事成績評定平均（地整全）に比べ相対的 には若干であるが高い結果となった。一方, 回帰直線 の傾きの推定值は 0.310 となるが，詔差を見込んだ
表-10 落札企業の前年度工事成績評定平均（発注同 事務所内）による工事成績評定の回帰分析表

\begin{tabular}{|c|c|c|r|r|}
\hline \multicolumn{5}{|c|}{ 回 帰 分 } \\
\hline 切片 & 傾き & $95 \%$ 下限の傾き & 相関R & 観測数 \\
\hline 51.657 & 0.310 & 0.245 & 0.292 & 946 \\
\hline
\end{tabular}

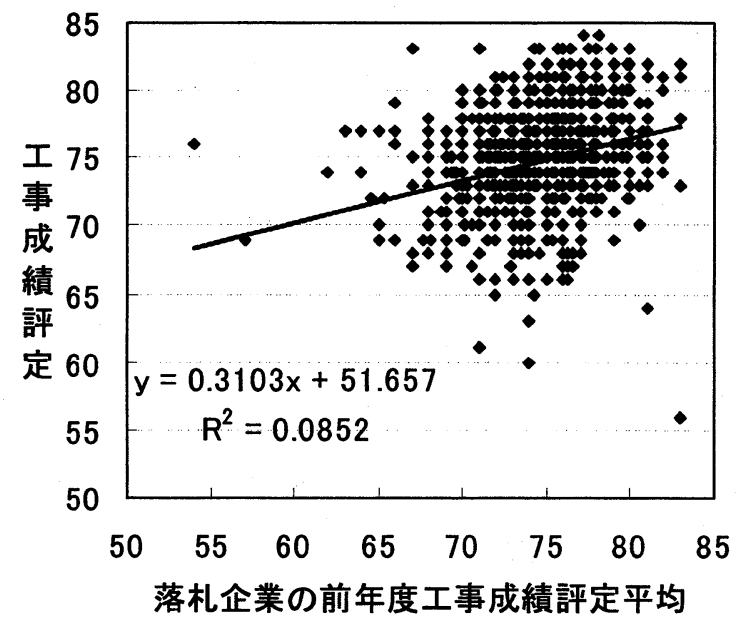

(発注同事務所内)

図-17 落札企業の前年度工事成績評定平均（発注 同事務所内）・工事成績評定の散布図

95\%信頼区間内において，傾きの下限值が 0.245 と解 析された. 従って, 前年度工事成績評定平均（発注同 事務所）の増加に伴う工事成績評定の上昇度合い（傾 き）は有意に 0 とはならず, 落札企業の前年度工事成 績評定平均（発注同事務所）が低くなるほど当該案件 の工事成䋶評定が低くなる傾向が統計的には示される 結果となった.

c）工事成績評定 65 点未満案件に着目した考察結果

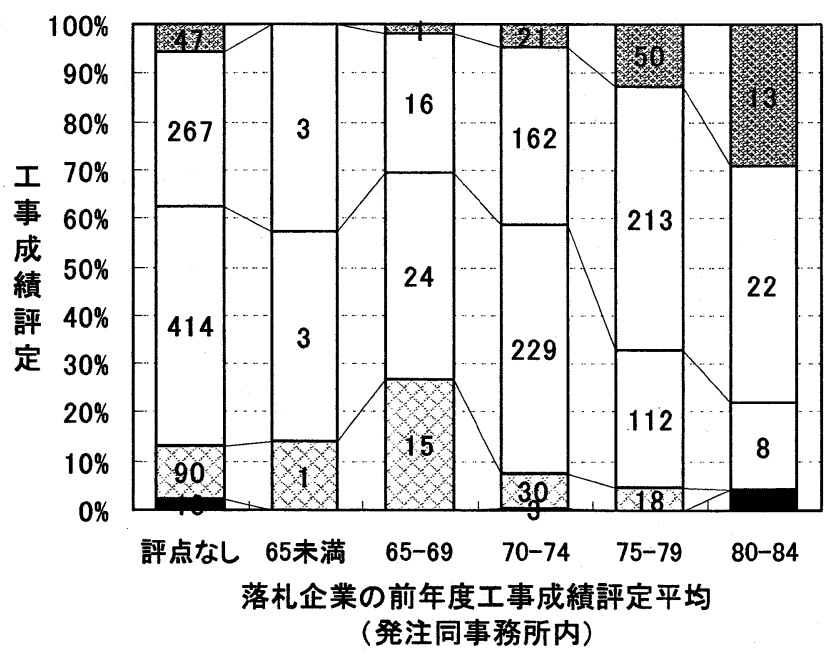

ロ 65未満 घ65-69 ロ 70-74 口75-79 圈 80-84 *「評点なし」とは分析対象工事発注事務所において, 前年度, 契約実 績が無い，随意契約等本分析対象テータに含まれない契約方式の実績, 当初契約金額が 500 万以下の工事成績評定評価外の契約実績を示す。

図-18 落札企業の前年度工事成績評定平均（発注同 事務所内）別・工事成績評定の件数割合 


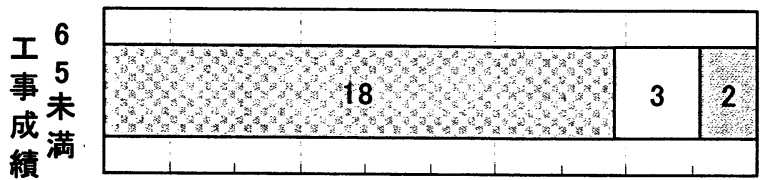

評 $0 \% \quad 10 \%$ 20\% 30\% 40\% 50\% 60\% 70\% 80\% $90 \% \quad 100$

定

落札企業の前年度工事成績評定平均 （発注同事務所内）

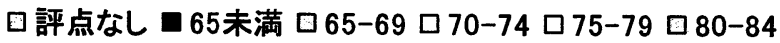

*「評点なし」とは分析対象工事発注事務所において, 前年度, 契約実 績が無い，随意契約等本分析対象テータに含まれない契約方式の実績 当初契約金額が 500 万以下の工事成績評定評価外の契約実績を示す.

図-19 落札企業の前年度工事成績評定平均（発注同事

\section{務所内）分布状況から見た 65 点未満の工事案件}

落札企業の当該案件発注同事務所内における前年度の 工事成績評定平均値別・工事成績評定の件数割合の結 果を図-18 に，また工事成績評定 65 点未満の案件の みを対象とした落札企業の当該案件発注同事務所内に おける前年度の工事成績評定平均值の件数割合を図19 に示す. 図-18 の結果より, 落札企業の前年度工事 成績評定平均（発注同事務所）が低くなるほど 65 点 末満の点数を取る割合が増大する傾向はみえない。ま た，前年度工事成績評定平均（発注同事務所） が低くなるほど 70 点以上の点数を取る割合の減少傾 向が「評点なし」案件群を除き概ね伺える結果となっ た. 一方, 図-19 の結果からは, 工事成績評定 65 点 未満の案件の約 8 割が「評点なし」企業群による工事 であるという結果となり，これは前述の四国地整全体 の結果に対してより顕著な特徽となっている.

\section{（7）工事成績評定と落札企業の発注同事務所内被指名} 回数との関係

上述(6)の分析における図-19 より，工事成績評定 65 点未満の案件の約 8 割が, 回帰分析では除外した

「評点なし」企業群による工事案件であることがわか った.このため, ここではこれらの案件群も回帰分析 でのサンプルとし取り扱える指標として，落札企業の 分析対象案件を発注した工事事務所における前年度の 被指名回数を（以下「落札企業の前年度発注事務所内 被指名回数」）取り上げ，当該案件の工事成績評定と の関係を分析する.

なお，本研究が対象としているデータは，前述のよ うに指名競争入札時代のデータであり，指名行為とは， 発注者の企業に対する期待感の表れと考えられる. そ のため, 当該案件発注同事務所内における前年度の被 指名回数が多い企業とは, 特定の地域における施工実
績から推定される施工能力, 地域における人材の雇用 と育成，災害対応や市民活動等の地域社会での貢献・ 交流，等々の総合的視点から発注者の評価が高い企業 となる傾向が強いと考えられる，すなわち，論理的に は，この被指名回数は総合的な地域性の視点を含んだ 企業評価指標と位置図付けられる.

\section{a）分散分析結果}

落札企業の前年度発注事務所内被指名回数の各区間 に含まれる案件群それぞれをグループとし, 工事成績 評定を特性值とした分散分析の結果を表-11 に示す. まず，P 值は極めて小さく統計的には有意な結果を示 した. また, 各グループの工事成績評定の平均值は, 前年度の被指名回数の低下とともに低下寸る傾向とな った.

表-11 落札企業の前年度発注事務所内被指名回数 による工事成績評定の分散分析表

\begin{tabular}{|c|c|c|c|}
\hline \multicolumn{4}{|c|}{ 分 散 分 析 } \\
\hline グループ & 0-3回 & 4-7回 & 8回以上 \\
\hline 標本数 & 910 & 420 & 452 \\
\hline 平均 & 73.34 & 74.38 & 75.23 \\
\hline 自由 & $2,1779)$ & -值 $1.62 \mathrm{E}$ & $17 * *$ \\
\hline
\end{tabular}

\section{b）相関，回帰分析結果}

工事成績評定を従属変数に, 落札企業の前年度発注 事務所内被指名回数を独立変数にとった回帰分析の結 果を, 図 -20 及び表 -12 に示す. 相関係数は 0.206 , 決定係数は 0.049 と 1 対 1 の相関関係は低く, 前述 （5）-b）（6）-b）の前年度の工事成績評定平均值に比べ ても相対的に低い結果となった。これは(5)-b) (6)b）の前年度の工事成績評定平均值を独立変数にとっ た回帰分析おいては除外した「評点なし」企業群が落 札した案件が，ここでは被指名回数の少ない企業の落 札案件としてサンプルに含まれているためと思われる. すなわち，これらの案件群の工事成績評定のばらつき が大きいことが相関関係を低下させたと考えられる. 一方, 回帰直線の傾きの推定值は 0.122 となるが, 誤 差を見込んだ 95\%信頼区間内において, 傾きの下限値 が 0.116 と解析された. 従って, 落札企業の前年度 発注事務所内被指名回数の増加に伴う工事成績評定の 上昇度合い（傾き）は有意に 0 とはならず，落札企 業の前年度発注事務所内被指名回数が低くなるほど当 該案件の工事成績評定が低くなる傾向が統計的には概 ね示される結果となった。 
表-12 落札企業の前年度発注事務所内被指名回数

による工事成績評定の回帰分析表

\begin{tabular}{|c|c|c|c|c|}
\hline & L & 帰 & 析 & \\
\hline 切片 & 傾き & 95\%上限の傾き & 相関R & 観測数 \\
\hline 73.23 & 0.148 & 0.116 & 0.206 & 1782 \\
\hline
\end{tabular}

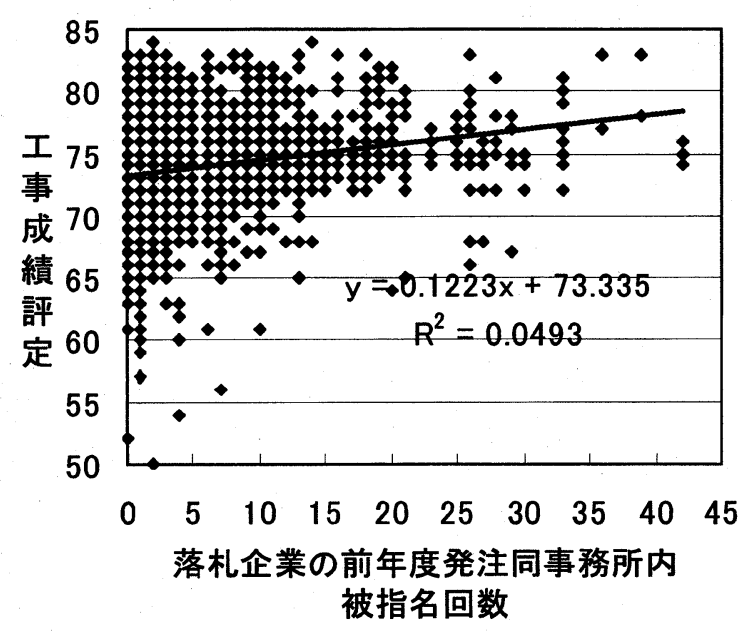

図-20 落札企業の前年度発注事務所内被指名 回数・工事成績評定の散布図

c）工事成績評定 65 点未満案件に着目した考察結果

落札企業の前年度発注事務所内被指名回数別・工 事成績評定の件数割合の結果を図 -21 に, また工事成 績評定 65 点未満の案件のみを対象とした落札企業の 前年度発注事務所内被指名回数の件数割合を図 -22 に 示す. 図-21 の結果より，前年度の被指名回数が少な くなるほど 65 点未満の点数を取る割合が若干増大す る傾向が伺える．また，前年度の被指名回数が少なく なるほど 70 点以上の点数を取る割合が減少傾向とな る結果となった. また, 図-22 の結果からも, 工事成

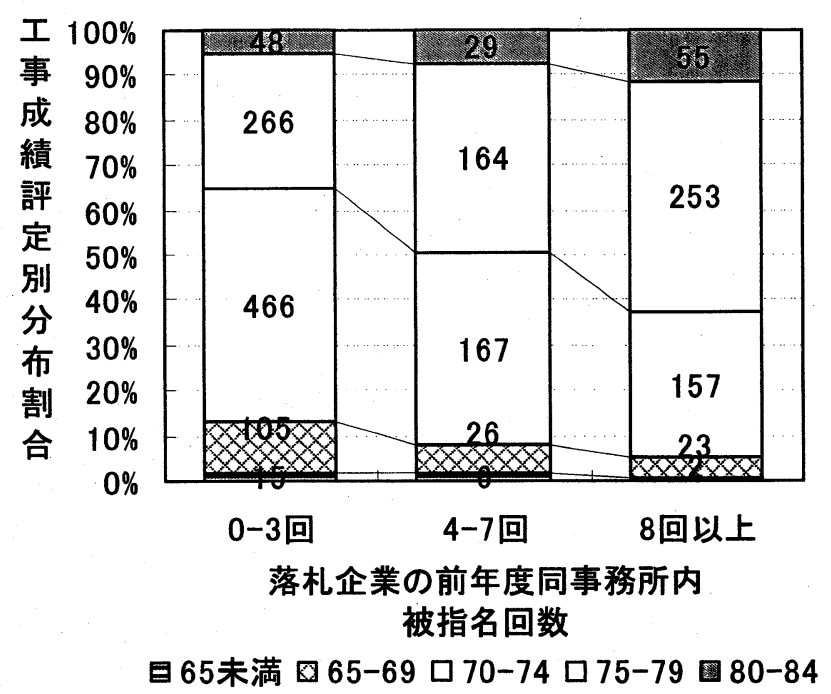

図-21 落札企業の前年度発注事務所内被指名回数

別・工事成績評定点の件数割合

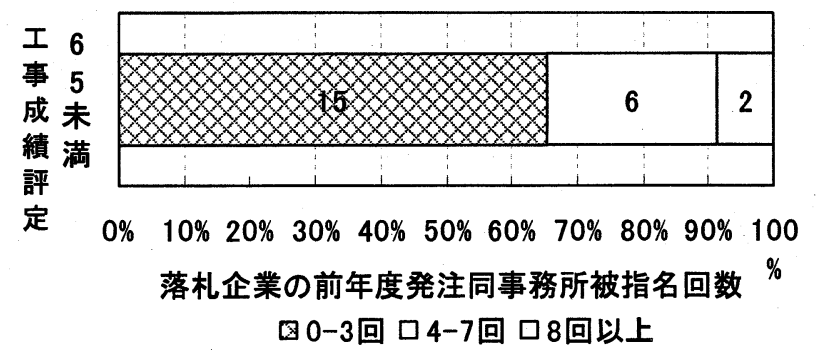

図-22 落札企業の前年度発注事務所内被指名回数 分布状況から見た 65 点未満の工事案件

績評定 65 点未満の案件の多くが落札企業の前年度発 注事務所内被指名回数の少ない企業が落札した案件で あるという結果を示している.

\section{4. 結論}

本研究においては，指名競争入札中心時代である 2002 2005 年度の国土交通省四国地方整備局におけ る工事案件データを対象に, 工事成績評定と, (1)落 札率, (2)価格競争状態, (3)落札企業の過去の工事成 績評定実績, (4)落札企業の過去の当該工事地域にお ける被指名実績との関係それぞれについて統計的分 析をおこなった. 以下，分析で得られた知見を示す.

(1) 工事成績評定と落札率や価格競争状態等の価格 に係わる指標との関係分析では，落札率と工事 成績評定には，統計的な関係性は否定できない. しかし，65 点未満の案件に関する分析（図-8） から，低価格落札のみが工事成績評定低下の要 因と断定できない結果となった。

(2) 工事成績評定と落札企業の過去の工事成績評定 実績との関係分析では，実際に工事成績評定 65 点未満となった工事の多くは，「評点なし（前 年度落札実績もしくは評定対象案件落札実績の ない）」企業群によって落札された工事である ことがわかった。またこの特徵は，四国地整 案件全体と比較して発注同事務所内に限定した 平均值算出結果の方がより顕著であり，工事位 置が特定された案件の成績評定と地域性を背景 とした施工能力との関係を分析することの重要 性が伺われる.

(3) 工事成績評定と落札企業の過去の当該工事地域 における被指名実績との関係分析において，分 散分析, 回帰分析等の傾向分析からは, 落札企 業の前年度発注事務所内被指名回数が小さくな るに応じて当該案件の工事成績評定も低下する 
傾向が算出されるとともに, 前年度の被指名回 数が少なくなるほど 70 点以上の点数を取る割 合が減少傾向となる結果となった。これは，我 が国の指名制度が，現在の工事を頑張ることが 次回以降の指名そして受注拡大に繋がるという

「好循環」を形成してきたこと意味するものと 考えられる. また, 工事成績評定 65 点未満の 案件の多くが前年度の被指名回数が少ない企業 が落札した案件であった。これは，指名制度が 有する，問題のある企業を排除する効果的なス クリーニング機能の表れであると考えられる.

(1)〜(3)より，落札企業の発注同事務所内における 過去の被指名回数が, 工事成績評定との関係におい て, 本研究で取り上げた指標の中で最も論理的整合 性が高く，地域性を背景とする総合的企業評価に関 するベンチマーク指標として今後の検討に值する指 標であると考えられる.

以上のような, 本研究で得られた知見を通して考 えられる, 今後の課題としては，以下のことが挙げ られる。

(1) 工事成績評定の持つ工事品質に対する信頼性の 程度と課題を, 発注者, 受注者, 学識経験者, 等々それぞれの観点からの聞き取り調査等を通 じて整理する必要がある．特に，任意の企業に おける複数年・複数回の工事成績評定平均值の 相対的比較には信頼性が欠けるとしても，ばら つき度合いの大小については一定の意味を有す るのか確認したい. その上で, 工事成績評定と 落札企業の過去の被指名実績との関係を, 本研 究で行ったような平均に基づく統計分析ではな く, 分散に基づく統計分析を用いてその傾向を 探ることが必要と考えている。これにより，我 が国の指名制度が有していた企業のモチベーシ ヨン誘発機能, 及びスクリーニング機能の効用 をより一層明確な形で検証・再評価したいと考 えている.

（2）各企業の過去の当該工事地域における被指名実 績と落札回数や落札確率（落札回数/被指名回 数）との関係を分析するとともに，指名競争中 心時代の発注者による企業の評価と受注状況の 関係が，現在の一般競争入札十総合評価方式一 の転換の過程でも如何に維持されているか，あ
るいは変化したかという視点からのモニタリン グを行う必要がある.なお，このようなモニタ リングが，新たな好循環システムの構築と円滑 な移行を評価する一つの方法論を提供するもの と考えている.

(3) また，各企業の当該工事地域における被指名実 績と各企業の複数年・複数回における工事成績 評定の安定性との関係をより一層精查するとと もに, 工事成績評定のみでの説明力の限界を把 握する必要がある.その上で, 地域における人 材の雇用と育成, 災害対応や市民活動等の地域 社会での貢献・交流, 等々の地域性に係わる要 素と当該工事地域における被指名実績との関係 を総合的に分析していく必要がある.

このような分析を通して，これまで指名という制 度の中に混沌と入り交じり集中していた，しかし結 果としては有効に働いていたと考えられる地域経 済 - 雇用への配慮機能, 地域の災害対応能力の維持 機能等々の地域性を背景とする各種機能を分解・整 理する.そして, 現在構築を目指している新たな建 設生産システムでは, 国レベル・県レベル・市町村 レベルあるいは都市空間・田舎空間の各々において， これらの機能を経営事項審査に配置するべきか, 総 合評価に配置するべきか，それとも政治的レベルに 配置するべきか，あるいは一定レベル以下の政治・ 行政・インハウスエンジニアリング能力では分散配 置自体が困難となるのか，等の機能デザインに関す る知見を得ていく必要がある.これらのことが，今 後の公共調達制度改革にあたって非常に重要となる。 指名競争入札制度の役割と効用を再評価し, 過去に 学ぶという基本姿勢を定量的アプローチのもとで行 う一つの方法であると考える。

\section{【謝辞】}

国土交通省四国地方整備局の皆様には貴重なデータ を提供していただきました。ここにお礼申し上げます。 本研究においてあり得べき誤謬はすべて著者の責に帰 すべきものです.

\section{【参考文献】}

1) 亀本和彦：公共工事と入札・契約の適正化一入札談 合の排除と防止を目指してー，レファレンス 2003.9，国立国会図書館，p. 18 
2)建設省建設経済局建設課：新公共入札・契約制度八 ンドブック 改訂 3 版 ，大成出版社. 1999.11, pp27-29

3) 新公共入札・契約制度ハンドブック 改訂 3 版，大 成出版社. 1999.11，pp5-134

4) 既出：新公共入札・契約制度ハンドブック 改訂 3 版，大成出版社. 1999.11，pp298-321

5) 既出, 亀本和彦: 公共工事と入札・契約の適正化一 入札談合の排除と防止を目指してー,レファレン ス 2003.9, 国立国会図書館，p. 20

6) 既出, 亀本和彦: 公共工事と入札・契約の適正化一 入札談合の排除と防止を目指してー,レファレン ス 2003.9，国立国会図書館，p. 20

7)西川和廣 : 公共工事の品質確保のための取り組みの 方向について，国土交通省国土技術開発総合研究
所年次講演会資料, 2006.12, p. 7

8)公共工事の品質を考える会 : 公共工事品確法と総合 評価方式一条文解説と Q\&A50 問一, 日刊建設工業 新聞社，2006.5.10 第 6 刷，p. 107

9）国土交通省直轄工事等契約関係資料，国土交通省 HP, http://www. mlit.go.jp/

10）平岡成明：勝ち残るための工事成績評定マニュア ル，株式会社山海堂, 2006. 5, pp27-32

11）国土交通省全国工事監視官等会議：工事成績評定 の分析 2006 年 3 月, pp. 10-26

12）岩松準, 秋山哲一, 遠藤和義 : 建設プロジェクトに おける入札戦略に関する研究日本建築学会計画系 論文集, 第 565 号, 2005. 4, pp. 120-123

\title{
Statistical analysis of the relationship between the number of times that the successful bidders were designated in past and quality of construction works focused on the 'locality' of bidders
}

\author{
By Emi MORIMOTO, Susumu NAMERIKAWA, Taichi OKAMOTO and Hideo YAMANAKA
}

\begin{abstract}
Various kinds of reformation have been implemented in the field of bids and contract system of public construction in Japan since 1993. Yet those reformations were promoted as a result of political and social pressure caused by collusive bidding at the initiative of government agencies, so that management systems based on performance evaluation on outcomes of those reformations haven't been improved. In this paper, based on the recognition above, Authors did a statistical analysis on the relationship between the performance of public works and various indicators as follows; a. the ratio of contract price to government's engineering cost, b. the competitive states, c. the past performance of the successful bidders, $d$. the number of times that the successful bidders were designated in past with the data of public works ordered by the Ministry of Land, Infrastructure and Transport Shikoku Regional Development when designated tender had been adopted mainly as public procurement. As a result, the indicator of $d$ (the number of times that the successful bidders were designated in past) is one of important indicators to valuate companies.
\end{abstract}

